\title{
Economic Solidarity Through Women Moslem Organization in response to Covid-19 Pandemic (A Case Muslimat NU Organization at Pringsewu Regency/Kabupaten Pringsewu)
}

\author{
Fitrianita Damhuri ${ }^{1, *}$ Meiliyana ${ }^{2,}$ Gita Paramitha ${ }^{2}$, S.Indriati Caturiani ${ }^{2}$, Hana \\ Soraya $^{2}$ \\ ${ }^{l}$ Women Empowerment \& Child Protection Board of Lampung Province \\ ${ }^{2}$ University of Lampung \\ *Corresponding author. Email: fitri.damhuri@gmail.com
}

\begin{abstract}
The covid-19 pandemics affects not only health system but also all sectors around the globe. All societies without exception facing challenging situation caused by the virus. Economic sector is one of the most affected in addition to health structure. The most concerned in the society is in the household level that they cannot afford for daily needs. This economic situation has forced women to get involved to fulfill family needs even play role as the head of the family since in every poverty, wherever worldwide, always illustrate females in the front.This article reveals the existence of Muslimat NU Organization offers an opportunity for women to activate an economic activities among women within the organization. The value of giving for charity (sedekah/shodaqoh) is the main motivation of their movement. Being women, moslems and actively engaged in moslem organization bring such advantages for them to build a network for their economic endeavor. Moreover, those economic activities contribute positively to deal with the economic impacts of covid-19 pandemic to household zone. The study was took place at Pringsewu Regency in Lampung Province which is third poorest region in Sumatera Island, Indonesia. The results of the research find that those activities potentially contribute to poverty alleviation in region thus should be supported by local government policies or programs.
\end{abstract}

Keywords: women, organization, economic activity

\section{INTRODUCTION}

Until the end of the 20th century, the problem of poverty was still a major issue throughout the world. For Indonesia itself, poverty is still a serious problem. Measurement of poverty in Indonesia is carried out by the Central Statistics Agency (BPS) using the concept of the ability to meet basic needs (basic needs approach) [1]. The number of poor people in Lampung in September 2019 reached 1.04 million people with most of them concentrated in rural areas, namely $13.96 \%$ while the rest were in urban areas as much as $8.60 \%$. When viewed from the composition of the population in Lampung Province, it has not been balanced with the contribution of women to economic activities as measured by the contribution of women's income which is one of the indicators for the Gender Empowerment Index (IDG), which has only reached 29.33 percent.

On the other hand, there is still a fairly high gap between the participation of women and men in employment, one of which is represented by the Labor Force Participation Rate (TPAK) indicator. LFPR is the percentage of the workforce to the number of people aged fifteen years and over [2]. In reality, it is undeniable that problems that often arise in families are caused by factors that have not been fully met. This economic factor then causes the role that should be supported by the husband to be assisted by a wife, or even the wife who acts as the "head of the family". The Integrated Social Welfare Data (DTKS) which ranks 40 percent of the people with the lowest level of welfare 
based on the Decree of the Minister of Social Affairs Number 146/HUK/2020 there are 132,684 female household heads out of a total of 999,769 poor household heads in Lampung Province or 13.27 percent.

Female heads of households bear economic responsibilities for their families, so that their participation in economic activities is very important for the welfare of their families. Another more fundamental problem lies in the dichotomous separation between the roles of men and women which is strongly contrasted with public and private roles. Patriarchal culture results in women being in a weak bargaining position. Therefore, gender mainstreaming in poverty reduction is an inevitable part.

Islamic teachings are more focused on binding humans to always obey the commands of Allah SWT and His Messenger and guide human life in various aspects of life, both with regard to the household and the community environment. In a household, husband and wife must be able to create tranquility, peace and prosperity for all family members. With the creation of comfort in the family, it is ensured that every family member can devote or donate their service to the community. Women play an important role in domestic life and Islam gives women the freedom to participate in society. Islam elevates the dignity of women in every development of the times [3].

Based on a pre-survey conducted in Pringsewu Regency, Muslimat Nahdatul Ulama (NU) of Pringsewu Regency as a community organization which is one of the Autonomous Body of Nahdatul Ulama which was established on March 29, 1946 is an organization whose priority program is women's economic empowerment. The participation of Muslimat NU in women's economic empowerment is expected to be a partner of the government in optimizing efforts to increase women's capacity and independence through a religious approach.

Taking into account the concentration of the poor who are mostly in rural areas, the almost balanced composition of the population between women and men and the large disparity in the contribution of women in the economic sector, empowerment of rural women is important for further in-depth research.

\section{LITERATURE REVIEW}

\subsection{Poverty}

Poverty is a human problem, so it carries the consequence of a moral responsibility for everyone to pay attention to the lives of people living in poverty.
Poverty is also a violation of human rights. "...human rights become a constitutive element of development and human rights violations become both a cause and symptom of poverty". Chambers as quoted by [4] suggests that the core of the poverty problem lies in the deprivation trap. The deprivation trap consists of five misfortunes that entangle the lives of poor families, namely (1) poverty itself; (2) physical weakness; (3) alienation; (4) vulnerability, and (5) powerlessness.

The Qur'an uses several words to describe poverty, including the words faqir, poor, al-sail and almahrum. However, the words faqir and poor are more often found in the Qur'an, in the Qur'an the word faqir is found 12 times and the word poor is found 25 times, each of which is used in different meanings [5]. However, the Qur'an itself does not provide detailed definitions for these terms. Poverty in the view of Islam is neither a punishment nor a curse from God, but is caused by a wrong human understanding of the distribution of income (sustenance) given.

\subsection{Community Empowerment}

The use of the term community empowerment is closely related to the community development paradigm that emerged from criticism of the economic growthbased development paradigm, which was put forward by Jim Ife, as follows: Empowerment means providing people with the resources, opportunities, knowledge and skills to increase their capacity to determine their own future, and to participate in and affect the life of their community. Empowerment should be the aim of all community development [6].

According to Agus Syafi'i, the purpose of community empowerment is to establish a community or build the ability to advance oneself towards a better life in a balanced way. Because community empowerment is an effort to broaden the horizon of choice for the community. This means that people are empowered to see and choose something that is beneficial to themselves [7].

\subsection{Gender, Feminism and Women Empowerment}

Starting from Ester Bosorup who criticized the welfare approach before the 1970s. In his book Woman's Role in Economic Development (1970) Boserup shows that economic growth and rural modernization in third world countries (Asia, Africa, Latin America) do not necessarily provide the same benefits and benefits to women and men, where many women are left behind in the production process to be replaced by machines, receive very low wages in the 
non-agricultural sector in urban areas, and are not even valued for their work in rural areas [8].

Then, feminist criticism of such economic development has been translated into an effort to integrate women in development through the Women in Development (WID) approach since the 1970s. The adoption of WID was marked at the first UN Summit on Women in Mexico in 1975, which introduced the term Women in Development (WID) to ensure the integration of women in development. However, Caroline Mosser noted that the anti-poverty approach used in WID to achieve gender equality, places more emphasis on reducing income disparities between women and men because it is believed that the source of injustice is poverty, and not sub ordination [9]. According to [10] the anti-poverty approach in WID is more focused on the reproductive role of women, for rural women in the third world who are attached to the conventional role and position of women as wives or mothers at home [10]. So, WID actually does not integrate women in modernization and economic growth, but instead marginalizes women.

So, seeing this trend, feminists in third world countries in the South (Global South Asia, Africa, Latin America) who are members of Development Alternatives with Women for a New Era (DAWN) call for WID to be replaced with Gender and Development (GAD) [11]. This is to integrate women's interests in modernization and economic growth, despite the fact that anti-poverty approaches are still being used.

\subsection{Theory of Islamic Community Development}

Ibn Khaldun explained that humans are individually given advantages but by nature humans have shortcomings. So that these advantages need to be fostered in order to develop personal potential to be able to build [12]. According to Ibn Khaldun, the development of Islamic society, the concept and purpose of developing an Islamic society are individuals, ashabiyah, ijtima 'al-insani society, the state and civilization.

Community empowerment has similarities with da'wah in the form of action. Progress will be obtained if someone is able to develop the potential in them. This is the same as the command of the Prophet who ordered everyone to work hard, worship obediently, be kind to everyone, maintain harmony in society. The task of empowerment actors is to encourage and create individuals and communities to be able to make changes in behavior towards independence (empowerment). Community development has the center of attention in helping people at various age levels to grow and develop through various facilitation and support so that they are able to decide, plan and take action to manage and develop their physical environment and social welfare [13].

\subsection{Lampung Success}

In accordance with the Lampung Provincial Regulation Number 13 of 2019 concerning the Lampung Province Medium-Term Development Plan (RPJMD) for 2019-2024, it is stated that the Lampung Province development vision for the 2019-2024 period is in accordance with the Vision of the elected Head and Deputy Regional Head: "

Taking into account the vision of development, it is hoped that the people of Lampung will become the "main subject" in regional development and in building their welfare. Development can be realized if it is supported by a sense of security and peace for the community and investors, supported by good and equitable public service facilities and infrastructure. Through these prerequisites, Lampung can grow into a developed area with intelligent (cultured) and competitive people so that mutual prosperity and prosperity can be achieved.

\section{METHODOLOGY}

This research is a qualitative research with a case study design. In this study they are: poor rural women as subjects and objects of economic empowerment, actors, designers, implementers and persons in charge of women's empowerment programs, as well as several stakeholders who can influence the gender perspective in society. This research will be conducted at the selected district/city level, namely Pringsewu Regency as the working area of Muslimat Nahdatul Ulama, Pringsewu Regency.

Informants in this qualitative research were selected by using purposive sampling technique, namely the method of determining the informants who were determined intentionally on the basis of criteria or sample objectives. In this study, the selection of informants was based on the following criteria and considerations: a) Planners, implementers, and assistance for empowerment programs for poor rural women, in this case Muslimat Nahdatul Ulama, Pringsewu Regency; b) Stakeholders who can influence the gender perspective in society; c) Rural poor women as implementers (subjects) and targets (objects) of women's empowerment programs.

\section{RESULTS AND DISCUSSION}

\subsection{Internal Condition}




\subsubsection{Islamic View On Women}

Islam is a universal religion. In Islam, work is something that is highly recommended. Moreover, working with a believer can not only prevent him from begging, but also can provide for his elderly parents and young children. Women who work outside the home must be able to invest their time perfectly and become a productive and beneficial component of society. Therefore, working women should not neglect the realization of the main and most important responsibilities for Muslim women.

In line with this, there are also interview data that explain that husbands or families support their partner's entrepreneurs by helping to find raw materials or other things because these businesses also help to fulfill family needs, but on the condition that household matters must be resolved first. Although there are those who substitute household tasks such as cooking for household assistants, the final responsibility lies with the mother who ensures that the task has been completed. This shows that women who are entrepreneurs as housewives and additional breadwinners have a double burden.

\subsubsection{Islamic Women's Organization}

The scope of the organization that is used as the object of research is Muslimat NU in Pringsewu Regency. Muslimat NU is one of the autonomous bodies of Jam'iyah Nadhlatul Ulama' (NU), where Muslimat NU members are NU women. This organization was born on March 29, 1946. During its journey, Muslimat NU joined other elements of the women's struggle, especially those who were members of the Indonesian Women's Congress (Kowani), a national-level federation of women's organizations. In Kowani, Muslimat NU occupies an important position.

The vision of Muslimat NU is the realization of a prosperous society imbued with the teachings of Islam Ahlusunnah wal Jama'ah in the Unitary State of the Republic of Indonesia, which is prosperous and just, blessed by Allah SWT. The missions of Muslimat NU are as follows: 1) Realizing the Indonesian people, especially women, who are aware of religion, society, nation and state; 2) Realizing the Indonesian people, especially women, who are qualified, independent and devoted to Allah SWT; 3) Realizing Indonesian society, especially women, who are aware of their obligations and rights according to Islamic teachings, both as individuals and as members of society; \& 4) Implement the goals of Jam'iyyah NU so that the realization of a just and prosperous society that is evenly distributed and blessed by Allah SWT.
Meanwhile, Muslimat NU in Pringsewu Regency has reduced these visions and missions to several work programs that are in accordance with the fields contained in the organizational structure of Muslimat NU in Pringsewu Regency.

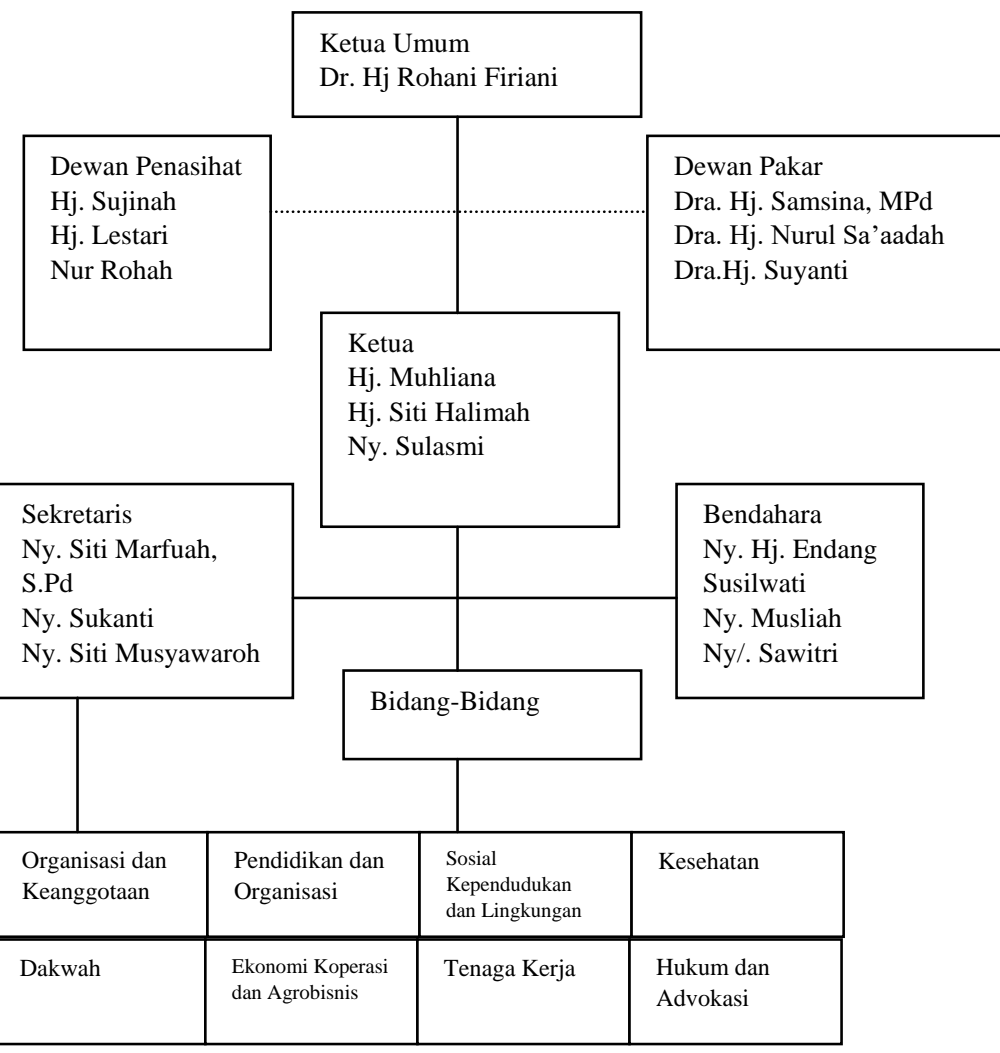

Picture 1. Organizational Structure of NU Muslimat Pringsewu Regency Period 2020-2025

Muslimat NU in Pringsewu Regency has 8 fields which have several work programs in empowering women, namely: Organization and Membership; Sector of Education and Cadre; Social, Population and Environmental Sector; the field of information/da'wah; Health; Economics, Cooperatives, and Agribusiness; Manpower Sector; and the Field of Law and Advocacy.

\subsubsection{Communal Economic Potential}

Alms is obligatory in Islam, because in the teachings of Islam alms is a good thing to reach heaven. This is in accordance with the religious base in the NU Muslimat organization. These women often carry out activities in the form of sodaqoh to others, both small and large scale. This charity activity is also a solidarity shown by the congregation towards fellow human beings. The application of solidarity that has been carried out includes NU Muslimat often conduct socialization to help people affected by natural disasters, such as donations for Palu, Donggala, Palestine, and other poor people. Then, there is also an institution that oversees the ambulance and free medical treatment, the 
institution is called LAZISNU (NU's charity infaq and alms). Then there are also heaven coins, which is an activity for distributing alms to the poor, elderly and orphans.

In addition, there are also agendas in the form of ta'lim or regular recitations, besides being filled with lectures, you can also find some worshipers who have businesses such as snacks taking them to ta'lim, and other worshipers help by buying their products. This shows that Muslimat NU as a means of organization also becomes a networking.

\subsubsection{Local Government Support}

There is cooperation with agencies related to coaching in the form of developing a home industry for pilgrims who have efforts to increase their capacity. The development of this home industry is carried out with several collaborations, such as the field of economic agribusiness and the Muslimat NU cooperative which collaborates with the employment sector for the development of women's economic empowerment.

The local government helps with related programs from various sectors such as the PPPA Service and Koperindag and often sends several workers to conduct comparative studies outside the region. Then, every year there is also a grant aid in the form of equipment with a total value of Rp. 10,000,000,00 which is given to small business groups.

The Industry sector also provides assistance in the form of equipment and guidance or training, for example sealer assistance, packaging guidance and marketing to large retailers such as Indomaret. The Koperindag Office also provides Food Safety Training. Then, there is also a program of providing free halal certification and socialization of industrial business permits. Business groups that have grown large are taxpayers, and the data that has received assistance from the PPPA Office is entered into the e-catalog form.

\subsection{External Challenge}

Before the pandemic, sometimes there was a schedule every Sunday morning with a "grazing" agenda, where local residents took a morning walk while making friends. Then there is also an agenda every Friday morning, namely the Farmers Market in the district government area by selling products produced by business groups. The products of these business groups are also marketed at certain events such as the Lampung Fair, Inakraf, or several anniversary celebrations of large organizations such as Muslimat NU.

\subsection{Women's Economic Empowerment Strategy}

Muslimat NU also held an LKM (Management Kembangmitra Training) at the end of January to the end of March 2021 in 9 sub-districts for LKM and home industry training. The skills obtained from the training were then competed, and the event also became a means of promotion to the local government, so that there were a lot of cake orders from Muslimat NU. After that, they were joined by a special community for the cake industry, which then the colleagues who received the training helped and trained other colleagues so that all of them had skills. The income obtained from the development of the home industry which is intended for charity will eventually also become a family income which significantly helps in meeting daily needs.

Furthermore, the researcher tries to see the economic activities carried out by Muslimat NU as one of the efforts to fulfill human needs as conveyed by Abraham Maslow (1943), namely there are five human needs: (1) physical needs, (2) security needs, (3) the need for belonging and love, (4) the need for esteem/recognition, and (5) the need for selfactualization. The need for actualization is the highest hierarchical human need [14]

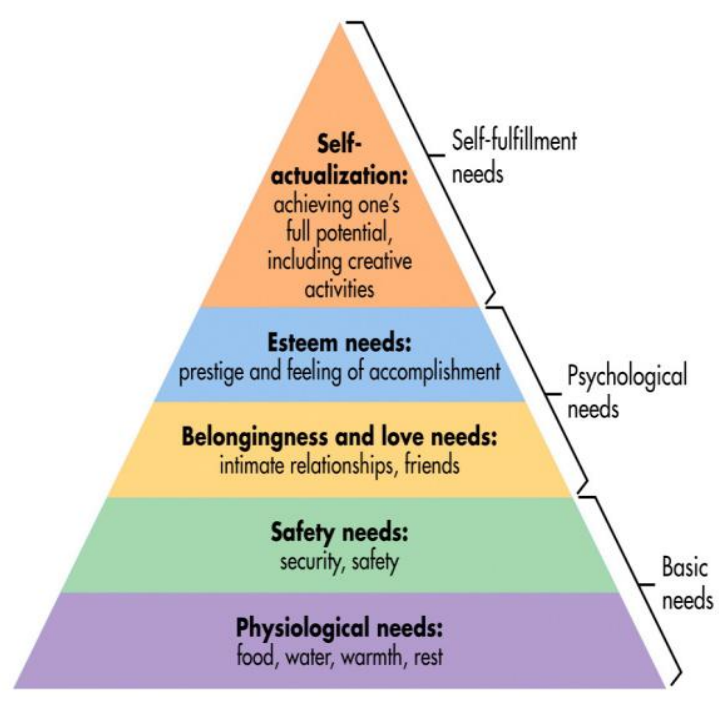

Picture 2. Maslow's Hierarchy Of NeedSource: McLeod, 2019

The involvement of women in the Muslimat NU organization and activities in the organization, encourages women to fulfill the need for belonging and love (having friends in the organization) and also being able to meet the need for appreciation/recognition from the surrounding environment that as part of society, these women are recognized as individuals. who can do things that are public. Organizing within Muslimat NU also fulfills the needs of individuals who are at the 
highest hierarchy, namely self-actualization, in this case worship (alms and or helping others) aimed at getting rewards (good deeds).

Furthermore, [15] in her article says that motivation is the thing that underlies a person's economic behavior. Motivation itself is based on the knowledge of the individual. So for Muslim women, they should make their knowledge about the demands in Islamic teachings as their motivation in economic activities [16]. This is reinforced by [17] who says that each religion has its own view of economic studies which will then be reflected in the economic behavior of followers of that religion.

One of the principles in Islamic economics is justice. That every individual must be given the opportunity to earn a halal living according to his ability. If the customs of the people who are unable to do so are due to the weaknesses that exist within themselves, then it becomes an obligation for other people to help Chapra in [15]. This then also became the motivation of NU Muslimat members in Pringsewu Regency to compete actively in carrying out economic activities in order to help other people in need. This behavior is in accordance with the principle of justice in the perspective of Islamic economics.

\subsubsection{The Calling Concept In The Protestant Ethic (Weber)}

The concept of calling refers to the idea that the highest form of moral obligation for individuals is to fulfill their duties in worldly affairs which are projected in religious behavior in daily mundane activities [18]. The view of Calvinism is considered the most influential in formulating the concept of calling. In this doctrine, the view "Only the elect can be saved from the curse, and that choice has been predetermined by God" encourages Protestants to work hard to become the elect.

This is also the same ethical value in the Islamic women's group (Muslimat NU) related to the spirit for activities so as to increase worship and also become devout Muslims. Entrepreneurship (economic) activities as an effort to become the chosen people.

\subsubsection{Communal Women's Economic Strengthening Scheme Design}

From the explanation above regarding the human need to have and love (friends), the need for appreciation/recognition for their work (work), and the need for self-actualization, this phenomenon has the potential to become a communal economic force. Where in this communal economy there is a sense of togetherness that can be the beginning to achieve equitable economic justice. In this study, the community (ummah) who fulfill their needs as mentioned above are Muslim women who are members of the Muslimat NU Pringsewu Regency.

As has been explained in the data description that in every joint activity carried out by NU Muslimat, they always set aside their wealth for alms for fellow members who are in need. This activity is carried out with the motivation to get goodness (reward) from Allah SWT. These women do things that become their knowledge in accordance with the demands of their religious teachings. They want to be the chosen one (the calling concept). If this continues to be encouraged, women's communal economic power to alleviate poverty can be achieved. Below is a diagram illustrating the factors for realizing the communal economy.

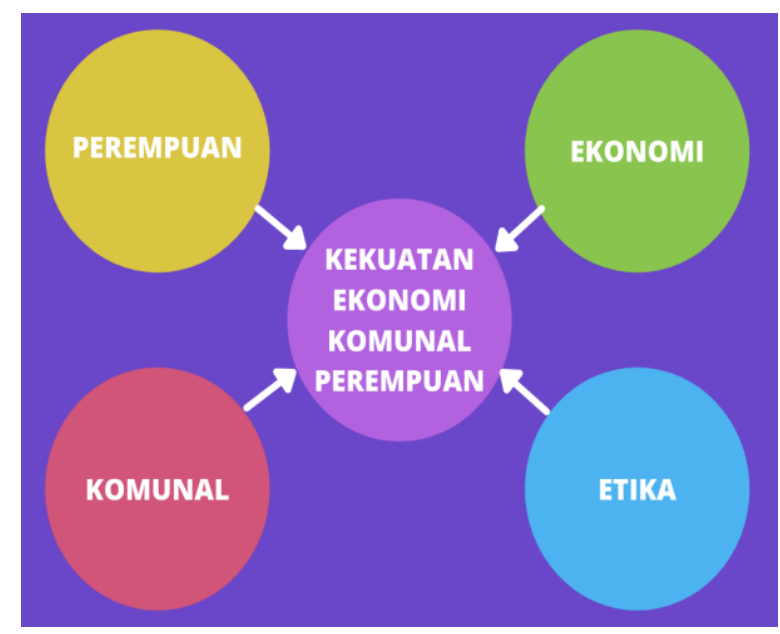

Picture 3. Illustration of Islamic Women's Economic Strategy. Source: Processed by Researchers, 2021

\section{CONCLUSIONS}

Based on research results, the conclusions of this study are as follows:

1. There are no significant barriers for women in carrying out economic activities, both from understanding the value of Islam, family, or the surrounding community.

2. Culturally, the view regarding financial responsibility is on men.

3. The economic activity carried out by women today still contributes to the informal sector and as an additional income, not the main income.

4. Muslimat NU as an organization serves as a forum for members who are active in the economy. 
5. The local government has implemented several programs related to women's economic activities, which are considered able to improve economic performance in Pringsewu Regency. Business requirements that have been running for two years are indicators of the basic ability of a business to achieve productivity.

6. The local government has not received an explanation about Lampung Berjaya.

\section{RECOMMENDATION}

1. In order to increase the economic capacity of women, it is necessary to form an organization or business group consisting of women. The recommended form of organization is a cooperative. This cooperative body can then cooperate with other business entities or the private sector. This needs to be done so that economic activities can be recorded and can also contribute to regional income.

2. Increasing the involvement of women's economic activities in Pringsewu Regency can be strengthened through local government programs. A training program to support production with stable production standards and capabilities for women's business groups. It also provides empowerment, increased economic capacity for women and business continuity.

3. Coordination of work programs between local government work units is needed, so that it can encourage the emergence of start-ups or new business ventures as an effort to leverage the opening of job opportunities.

4. Goal setting in the Lampung Berjaya program in the Pringsewu Regency regional regulation.

\section{REFERENCES}

[1] https://lampung.bps.go.is/subject/23/ kemiskinan.html\#subjek

[2] https://www.bps.go.id/

[3] Hadijah Salim, Wanita Islam Kepribadian dan Perjuangan, (Bandung: Remaja Rosda Karya, 1994). hlm. 8

[4] Soetrisno, Loekman, Substansi Permasalahan Kemiskinan dan Kesenjangan. Dalam Dewanta (ed),Kemiskinan dan Kesenjangan di Indonesia, (Yogyakarta: Penerbit Aditya Medi, 1995), hlm. 19
[5] Muhtadi Ridwan, Geliat Ekonomi Islam: Memangkas Kemiskinan, Mendorong Perubahan, (Malang: UIN Maliki Press, 2012), hlm. 31

[6] Ife, Jim, Community Development: Creating Community Alternatives: Vision, Analysis, and Practice, (Australia, Longman, 1995), hlm. 5

[7] Agus Ahmad Syafi'i, Manajemen Masyarakat Islam, (Bandung: Gerbang Masyarakat Baru, 2001), hlm. 39

[8] Ester Boserup, Woman's Role in Economic Development (Great Britain: George Allen and Unwin, 1970).

[9] Mosser Caroline , Gender Planning in thethird World: Meeting Practical and Strategic Needs, dalam Rebecca Grant and Kathleen Newland (eds.), Gender and International Relations (Suffolk: pen University Press, 1991), hlm. 101.

[10] Geeta Chowdhry, Engendering Development: Women in Development (WID) in International Development Regimes, dalam Marianne H. Marchand and Jane L. Papart (eds.), Feminism/Postmodernism/Development (London and New York: Routledge, 1995), hlm 32 .

[11] DAWN adalah forum kerja sama dan komunikasi antara perempuan di negara negara dunia yang menyadari bahwa WID justru meminggirkan perempuan Lihat DAWN, "Rethinking Social Development: DAWN's Vision," World Development 23, no.11(1996).

[12] Muhtadi dan Tantan Hermansyah, Manajemen Pengembangan Masyarakat Islam (PMI), (UIN Syarif Hidayatullah Jakarta: UIN Jakarta Press, 2013), hlm. 6

Totok Mardikanto \& Poerwoko

Soebiato, Pemberdayaan Masyarakat dalam Perspektif Kebijakan Publik, (Alfabeta, Bandung, 2019), hlm. 75

[14] Qomar, M. N. (2019). Pandangan Al Quran Tentang Perempuan Bekerja (Hikmah Dibalik Surat Al-Qhashas). Jurnal Harkat, 15(1).

[15] Astuti, R. (2011, April). Rekonsepsi Ekonomi Islam dalam Perilaku dan Motivasi Ekonomi. Religia, 14(1), 75-92. 
[16] McLeod, S. (2019, December 29). Maslow's Hierarchy of Needs. Diambil kembali dari Simply Pshycology: https://www.simplypsychology.org/maslow.htm $\underline{l 7}[17]$

[17] Syaefudin, AM. (1997). Filsafat, NilaiDasar, Nilai Instrumental dan Fungsionalisasi Konsep Ekonomi Islam, JKTTI - No 1-I

[18] AS, M. (2006, Juni 17). Etika Protestan dan Spirit Kapitalisme. Diambil kembali dari NU Online:

https://www.nu.or.id/post/read/8016/etikaprotestan-dan-spirit-kapitalisme 